\title{
Appraisals of Britain's Military Strength and War Propaganda
}

\author{
[Britain] is convinced that the life of the British citizen is too precious \\ to be risked in the petty fights among continental countries. ${ }^{1}$
}

OR MUSSOLINI, WAR WAS the greatest test of nations and ideologies, and it was the pursuit of war and imperial expansion that led Fascist Italy down the path of hostility with Britain. ${ }^{2}$ However, war itself proved the doom of the Fascist experiment, mainly at the hands of the British Empire. The Italian Fascist representation of Great Britain from a military point of view is therefore both interesting for understanding the dynamics of Fascist ideology and its centrality to the development of Fascist foreign policy. In order to assess it, it is particularly interesting to analyse the reports of Italian military attachés in London, mid-ranking officers who enjoyed a direct contact with British military culture. As we will see, they also had a remarkable influence on the higher ranks of Italian military and political elite.

Before the Great War, British martial aptitude was widely admired. The Italian attaché in London before and during the Great War, Lieutenant Colonel Edoardo Greppi, showed an 'evident Anglophilia' and appreciation for Britain, with 'its gigantic empire, the sobriety of its costumes and the good demeanour of the people, the admired military virtues and the patriotic dedication of its ruling class.' Furthermore, he was fundamentally in agreement with the political and military policies chosen by the British authorities. ${ }^{3}$ Likewise, during and after the Great War, Mussolini had shown respect and admiration for the British Army and the British people's military qualities. In December 1917, he praised the power and efficiency of the British Army, and shortly afterwards resolutely denied that Britain waged what the Germans called 'the War of the Usurers,' that is, having the Italians and the French die for it. ${ }^{4} \mathrm{He}$ also mentioned the 'impressive' cohesion of the British people behind the war effort. ${ }^{5}$ Commenting on the beginning of the German offensive in March 1918, he stated that his 
confidence in a British victory was also rooted in the human factor, contrasting by implication the British with what happened in Italy, where, according to him, Socialists, unpatriotic pro-Germans and deserters boycotted the national war effort. According to Mussolini, 'the English soldier does not desert. He does not surrender. England has no deserters. The English soldier knows why he fights. He has the sense, the individual consciousness of his responsibility.' ${ }^{3} \mathrm{~A}$ few days later, he added that 'the admirable English divisions [. . . fight for us as well. [On] them depends our destiny.'7 In December 1918, after the end of the war, he commented on the British elections stating that 'the English nation is rallied around the government and the men who fought the war and snatched the victory. ${ }^{8}$ Such a perception radically changed in the following years, in particular after the end of the 1920s. From an analysis of the Italian attachés in London during the 1930 s emerges a growing belief in British military weakness and contempt for the British people's military virtues and will to fight.

The Italian perception of Britain as a military power evolved dramatically in the years between the First World War and the Second World War. The reports from the attachés during the early 1920s mostly focused on technical issues; during the second half of the 1920 , however, an interest in British military innovations can be found in the reports. In 1927, the attaché Lieutenant Colonel Amerigo Coppi had already shown an enthusiastic interest in the mechanisation of the British Army. Coppi believed that mechanisation was the right direction for the British Army and, to a lesser degree, for continental armies as well. ${ }^{9}$ His successor was to devote even more attention to the subject, without, however, neglecting a broader assessment of Britain's domestic and international situation.

Lieutenant Colonel Adolfo Infante described a nation that had been critically hit by the economic crisis, was politically unstable and increasingly weakened in its international position by US competition and the desire for independence of the Dominions and Colonies. ${ }^{10}$ The root of the economic troubles was, in Infante's view, a lack of competitiveness in the British economy, weakened by high salaries and the weight of generous unemployment benefits, which were necessary to preserve social peace. ${ }^{11}$ For the first time, Britain's place as the greatest world power seemed uncertain and it is not difficult to discern that, in Infante's view, the reason was that Britain lacked a form of corporatist discipline like the one that existed in Italy. In October 1930, Infante noted a general sense of depression and pessimism, a remarkable contrast with the usual British optimism. ${ }^{12}$ Nevertheless, he was convinced that Britain could still regain its strength, even if it was clear that it would require time and that maintaining its position visa-vis the United States was an impossibility: 'The strength of the great qualities 
of British character will certainly allow the country to overcome the current economic crisis (which is global). ${ }^{13}$ If this political assessment adhered closely to ideas common in Italy at the time, Infante looked at military matters in a very different way. Despite a lack of funding, the army had managed to improve its organisation and,

since the beginning of 1929, [had been] going through a crisis of deep transformation, mostly due to the mechanization of many units and to the many experiments to define the new organic constitution of the infantry Brigade and of the Division. The problem of mechanization of the army is today the fundamental problem [that] is most studied, experimented and debated. ${ }^{14}$

Mechanisation had progressed a great deal, particularly with the first manoeuvres involving tanks, the creation of the Tank Corps and the introduction of a new model of tank. These improvements were combined with a vast and innovative operative experimentation, so that 'it could be said that [Britain] is ahead of all nations not just in terms of materiel but also for its employment. ${ }^{35}$ Infante was a careful observer of mechanisation; he made two very detailed reports on the so-called Purple Primer and recorded the troubled constitution of the Armored Brigade and its employment in the manoeuvres of 1929, the introduction of Charles Broad's Tank Brigade in I93I and its brilliant success in that year's manoeuvres. ${ }^{16}$ Observing the manoeuvres, he wrote of the mechanised units' possibilities for achieving surprise and of their extreme mobility, the efficient cooperation between light and medium tanks and between tanks and infantry, the progress in radio communication, and of how tanks had changed war, bringing it back to the 'classic art of Napoleonic manoeuvres.' He did not hide his admiration when describing 'a great deal of really great issues and new problems, which, while they might appear still far in the future, are in Britain already studied, analysed and practically faced. ${ }^{17}$

Infante's replacement from 1933, Lieutenant Colonel Umberto Mondadori, even while acknowledging the progress of army mechanisation in Britain, was already clearly giving in to an ideological worldview. Possibly influenced by British economic difficulties, he claimed that Britain had 'growing enthusiasm for the Fascist 'totalitarian' conquest [...] of Italian society. ${ }^{\text {18 }}$ Mondadori described the British Army in increasingly grim terms, contrasting its old-fashioned operational doctrine with the most modern Italian 'mobile' warfare. He wrote that, in terms of mobility, Italy was ahead of Britain. In Ethiopia, in fact, Italy was not going to employ those 'old infantry formations' still used by the British, instead using its 'Mobile Divisions,' which represented its most modern and perfect 
instrument of war. The fact that he was referring to the new, slim 'hay and oil' Italian Celeri Divisions hints how far he was already detached from reality. ${ }^{19}$ In his summary report for 1935 , he wrote that 'what is remarkable in these manoeuvres is the feeling that the army is in a state of disarmament; the organics are extremely reduced, armament and equipment are seriously lacking' and at the beginning of 1936 , he highlighted the anxiety of public opinion on this topic. ${ }^{20}$

It is hardly surprising then that during the Ethiopian War Mondadori claimed that British forces in Egypt were still in a peacetime condition, and that an Italian advance towards the Suez Canal would pose a significant threat to British imperial communications. ${ }^{21}$

He also concluded that Britain was unable to provide anything other than air support to its allies in case of war. ${ }^{22}$ His opinion was shared by the naval attaché in London, Ferrante Capponi. Reporting on the French-British meetings following the German reoccupation of the Rhineland in 1936, he underlined French scepticism caused by the lack of '. . British military preparation [...]. Regarding the army, it is abundantly clear for the French that the British forces could cross the channel, if necessary, only with huge delay. ${ }^{23}$ The issue of the role the British Army would play in a continental war was widely discussed by Lieutenant Colonel Cesare Ruggeri Laderchi, attaché in London from 1937 to 1939. British reluctance to expose themselves to any risk is a recurring theme in his reports, perfectly matching the new Fascist image of the declining, cowardly and satisfied Western democracies. In March 1938, Laderchi wrote a report on British rearmament in which he claimed it had a merely defensive purpose, in accordance with the people's opinion that British lives were too precious to be risked in petty fights among continental countries. Laderchi was convinced that rearmament was in no way a prelude to a more 'active,' if not quite 'offensive,' British foreign policy:

Great Britain does not want to be dragged into a new European war. Who fought it emerged from it with a feeling of disgust, has taught his children in the belief that war in Europe 'is not for the British,' and is convinced that the life of the British citizen is too precious to be risked in the petty fights among continental countries. ${ }^{24}$

The issue of material was a different matter. British rearmament was meant to assure Britain's European allies it had the necessary means to defend its interests in Europe.$^{25}$ Eventually, Laderchi convinced himself of the possibility of a British intervention in Europe but, in September 1938, he characteristically wrote that the mechanisation of the British Army had encouraged aversion for the 
arduous, routine part of the conflict, which was to be left to the Allies, reserving for themselves only the most decisive and glorious actions. ${ }^{26}$ His contempt for the British character was as strong as the high esteem in which he held its Fascist counterparts: he repeatedly attacked British newspapers, which, according to him, underrated Italy's military might. In January 1938, reporting on some Daily Telegraph articles in which the Italian strategic situation was described as 'weak' and it was claimed that Britain was in a stronger position, the attaché dismissed them as 'War Office propaganda.' Such propaganda was, the officer believed, aimed at convincing British public opinion that, in the case of conflict against Italy, Britain would not be 'in that bad condition,' as well as at introducing the audience to the much-debated and feared idea of a conflict with its Mediterranean adversary. In another article, it was stated that Italy had no history of military successes, that Italian soldiers in Spain had not behaved brilliantly and had suffered a defeat at Guadalajara, and that the Abyssinian campaign, while an organisational and mechanic triumph, had been a military walk in the park that did not particularly add much to Italy's military reputation. Laderchi, who seems to have been offended, dismissed the author as insolent and ignorant of Italian military glories. He was equally annoyed by the reaction of the British press to the Italian annexation of Albania in April 1939. The occupation had not been depicted as a success by the Italian armed forces, and British newspapers had not analysed the reasons behind such a quick and masterful action. The silence that had followed the first attempts to discredit the Italian action was, in the attache's eyes, the best recognition from the British (who had lost their traditional sense of fair play) that they had recognised Italy's success. ${ }^{27}$

\section{The Military Attachés and the Elite}

Commenting on the aggressive direction assumed by Fascist foreign policy between 1936 and 1939 (in February 1938, Mussolini informed the Germans that he intended to attack the British by himself), Denis Mack Smith argued that such a policy was based on what he claimed to be crushing proof of the superiority of the Italian armed forces over the British. Mussolini's 'general staff encouraged him by reporting that their military preparations [. . . had outstripped those of Britain. ${ }^{28}$ The general staff, continued Mack Smith, could hardly have been honest in claiming that, and Mussolini himself could not ignore the truth. There are, however, sufficient indications that the general staff was indeed convinced of the superiority of the Regio Esercito over the British Army. ${ }^{29}$ The undeniable Mussolinian knowledge regarding the weakness of Italy might have been far 
more concerned with acknowledging the strength of the French Army, which the military attachés considered the strongest in Europe and that was a model for the Italian Army. ${ }^{30}$ It is unlikely that the deep underestimation of the capability, as well as of the will of the British Empire to fight had no effect on the aggressive policies Mussolini pursued in the last years before the conflict.

One example is Laderchi's report to the Chief of General Staff and Undersecretary of War, Alberto Pariani, in June 1938. The occasion was the unusual meeting of the Italian military attachés stationed in major countries, called by Pariani to update him on the European military balance in that time of increased risk of war. According to Laderchi, Great Britain wanted peace at any cost and wished only to defend what it already had; the support the British could provide to France was limited to the Air Force; and the British Army was going to be mechanised but would not be ready before 1940. The following exchange between Laderchi and Pariani regarding the British situation in the event of conflict is important because it underlines how Pariani accepted Laderchi's point of view on the subject without question:

- Pariani: I would want to know what is the effort Britain is capable of, in case of conflict.

- Laderchi: It could provide 170,000 men, which is to say the whole army currently existing, for the defence would be dealt with by the territorial army.

- Pariani: Few [men]. That's why Britain wants peace at any cost. ${ }^{31}$

These words, and Pariani's contemptuous attitude towards democracies, can help to explain why, at the time of the Czechoslovakian crisis in September 1938, Mussolini boldly declared that he could fight both France and Great Britain in the Mediterranean, threatening Tunisia and Egypt. ${ }^{32}$ Pariani had already claimed in 1937 that, once his new, agile army was ready, Italy could crush Egypt and Sudan 'whenever and however we want,' and a detailed report dated June 1938 - which was drafted by the 'Operation office II' - described Britain as forced to avoid any 'bellicose attitude' by the scarcity of its forces and by its own strategic doctrine. ${ }^{33}$

At this point it is interesting to note that, despite Pariani being convinced that the decisive front of the future war would be the Cyrenaican-Egyptian border, in this and in most of the reports by the attachés very little attention was given to the colonies. Such an attitude was consistent with Badoglio's and others' belief that the colonies were an inconvenient waste of resources in the case of conflict, and that the war would have to be fought in Europe. Pariani himself, convinced that he would be able to overrun Egypt easily with his guerra di 
rapido corso (in that, as we have seen, probably influenced by the reports of the attachés), seemed satisfied with reports that mostly dealt with possible British intervention in Europe. ${ }^{34}$

Even if by October Laderchi was convinced of the importance of British rearmament, his overall judgment of the British Army remained negative. In a SIM (Military Information Service) report of December 1938 - presumably written by Laderchi - it was claimed that the political crisis in Central Europe had caught the British Army in a critical phase of transition from an obsolete and inefficient instrument into a new, experimental army that still faced numerous problems, including the lack of men, the critical condition of materials in both quantitative and qualitative terms and the incomplete progress of motorisation. ${ }^{35}$

Laderchi was not the only attaché convinced that Britain had no will to fight. At the beginning of 1939, the naval attaché Rear Admiral Brivonesi wrote in a personal letter that but for some warmongers and businesspersons, Britain hoped to avoid conflict because it had nothing to gain, a notion the French were aware of. Brivonesi saw a lack of men willing to fight as the root of Britain's problems. Nobody wanted to wear a uniform anymore, almost as if soldiers were ashamed to wear one, the common opinion being that only the good-for-nothing served the nation on the battlefield: such, in Brivonesi's eyes, was the basis of the less-than-virile reaction of the British people to the Munich crisis of $1938 .{ }^{36}$ In another SIM report dated March 1939, it was stressed that 'Great Britain's rearmament, while huge, shows a serious structural problem: it is basically based on the machine factor instead of the human one. The spiritual and material lacunae deriving from that are obvious. ${ }^{37}$ While the claim that a rearming program's flaw was that it was based on materials rather than on men can seem absurd, it perfectly fit the picture the military attaché had of Britain: a country abundant in capital but lacking in morale. Indeed, the anachronistic idea of the preeminence of 'spirit' over 'matter' was another pillar of the Fascist worldview, continuously stressed by Fascist propaganda. ${ }^{38}$ Furthermore, it proves that, rather than involving only the military attachés, the Fascistisation of the SIM had made it as biased a source of information as Laderchi. After the start of the war, Laderchi himself proved once again how his ideas and his overestimation of the Italian Army influenced his analysis, claiming, for example, that the German campaign in Poland was more or less a repetition of Mussolini's strategy in Ethiopia. ${ }^{39}$ His contempt for the British character emerged once again in April 1940. Describing the ongoing campaign in Norway, he mentioned that the British people were particularly gullible to propaganda, for their mind-set was such that at the slightest good news from the front they could finally say: 'the war is 
going well: so let's go [have] a good time. ${ }^{30}$ Such reports were consistent with an analysis of the British military potential written by the SIM in 1940. According to this analysis, the strength of the British Empire lay in its huge manpower ('8.5 millions of fighters,' echoing Mussolini's famous ' 8 millions of bayonets' speech). The author, however, claimed that to draw too pessimistic conclusions was wrong: after all, the outcome of a conflict was not decided only by the number of bayonets that could be deployed on the first line with time. It was far more important that those bayonets could reach the principal front. Such an operation was far from safe, since the seas were threatened by enemy forces and British forces abroad had to defend the colonies and Dominions. More important, the Empire would need considerable time - a year or two - to mobilise its forces, and in such a time span many things could happen, in Europe and in the world, that could neutralise imperial mobilisation. The British Empire, the report concluded, was surely powerful, well protected and not to be underrated. Its armour, however, showed 'cracks that would allow a sharp and well-aimed dagger (ferro) to reach its vital organs.' Like all giants, the Empire was heavy and slow in its movements. If confronted by an agile and mobile enemy, it risked much. In conclusion, the British Empire was an enemy not to despise, but one that could be beaten. ${ }^{41}$ Recent research has showed how the Regia Marina also underrated the Royal Navy. During the interwar years, and in particular after the Washington Naval Conference in 1922, Italian navalist thinkers started revising their previous assessment of the British Empire as the obvious and necessary ally of Italy on the seas. As historian Fabio De Ninno has explained, if in the first years after the Great War the officers who had grown up in a world where the Royal Navy ruled the seas, in subsequent years many of them became convinced that the British Empire was a declining force. As early as 1930, the important navalist thinker De Giamberardino expressed his scepticism of pursuing a policy of close friendship with London, pointing to both the divergent interests of the two powers and the state of decline of the British Empire. ${ }^{42}$ Even when it came to maritime issues, then, Britain was perceived as increasingly weak. By the time of the declaration of war in 1940, the belief that the obsolete aeroplanes and submarines Italy possessed would be enough to face the British Empire was widespread. ${ }^{43}$

Italo Balbo, Governor of Libya, shared the Italian Armed Forces' point of view. In September 1939 he claimed that, despite the unfavourable position of the Italian forces defending Tripoli against the French, he had no intention of giving up his offensive in Egypt, 'especially to acquire lands far richer than Libya. ${ }^{\circledR 4}$ He did not bother mentioning the British forces defending the country. The reports written by the attachés probably influenced Dino Grandi, Ambassador 
in London from 1932 to 1939 (whose military information mainly came from the attachés), in his remarks to Mussolini about a decadent and unwarlike Britain, which was 'slow, fat, heavy, sleepy, with weak sight and even weaker nerves' and whose soldiers were no match for the Italians. ${ }^{45}$ Ciano's claim that the British feared a new conflict 'more than any other [people] in the world' hinted that he had also accepted such a point of view. ${ }^{46}$ In September, the foreign minister added that 'in the English streets [the people] kneel and pray for peace. In Italy they wait with strong and aware calm,' while in January 1939 he wrote in his diary that 'the British do not want to fight. They try to withdraw as slowly as they can, but they do not want to fight. ${ }^{37}$ While Ciano was eventually converted to the anti-German camp, and was far more convinced than Mussolini about the British potential to resist after the fall of France, during the 1930 s he was as convinced as anyone that the British were not a people of warrior material.

How accurate was this perception? The British Army was indeed in a dire condition during the 1930s. As a consequence, the role of the British Army as a European fighting force in the upcoming conflict was widely debated, with the consequence of angering and worrying the French. The necessity of rearmament and the process of mechanising the army were also taking their toll; the British Army was restricted by budget issues and by its limited size during the late 1930s. ${ }^{48}$ In this sense, the attachés' perception was correct, as they witnessed a moment of real weakness of the British Armed Forces. However, this weakness was relative. The attachés' lack of appreciation for the still-immense difference in military strength, as well as technological advancement, of the British and Italian armies produced an exceedingly optimistic assessment that would prove disastrous. At the same moment in which Mondadori described how great a menace the Italian forces in Libya were to the British in Egypt, as Steven Morewood has underlined, the British commanders who were actually in charge of defending the British position in Africa and the Mediterranean did not doubt they could prevail over Italy with ease, with or without allies. ${ }^{49} \mathrm{After}$ the end of the Ethiopian War, the defence of Egypt was, however, neglected and remained so until the Italian entry into the Second World War. Even after the war with Germany had begun, preparations for an Italian invasion of Egypt were constrained by the idea that extending the war to the Mediterranean could be avoided..$^{50}$ The triumphal idea that the Italian Army was more modern and more motivated than the British, and that it could hence easily take over British forces in North Africa, however, was unrealistic, and was not accepted by the British themselves, even in their weakened state. In summer 1939, for example, General Sir Archibald Wavell was convinced that the danger presented by a possible Italian invasion 
of Egypt was remote. ${ }^{51}$ The notion that Italy could be beaten without too much effort was widespread among those British military and naval officers who had observed the Italian Armed Forces. ${ }^{52}$ The reasons for the temporary weakness of the forces garrisoning Egypt, as well as the reluctance to establish a massive continental army, were, respectively, connected to the low priority British planners gave to Italy in comparison to Germany and Japan and to budget restrictions and strategic disputes. Like the Fascist commentators who assessed British economic and social troubles of the 1920 s and the 1930s, the attachés interpreted these facts in an ideological way, drawing their own conclusions. Nor did the attachés' perception change after the British had begun a rearmament project that easily dwarfed anything Italy could even consider; instead, the admiration Infante had shown for British technical professionalism and will to experiment with mechanisation had been succeeded by Mondadori's completely unrealistic assumption of Italian superiority, as well as an utterly ideological dismissal of the rearmament as too focused on material factors. A comparison of reports by Infante, Mondadori and Laderchi underlines how reality was increasingly bent by ideological lenses. However, the attache's fundamental blunder was that, contrary to what many Fascists believed, appeasement did not mean a lack of will to fight. As Morewood puts it, 'appeasement represented a means to uphold the British Empire, not relinquish it. ${ }^{33}$ British weakness was real to a certain degree, but it did not mean that Rome was well equipped to face London.

\section{Undying Stereotypes: Public Discourse before the Loss of Africa}

During the early years of Fascism, there was no innate contempt for the military qualities of the British people in Italy. Like most Italians, Mussolini respected Britain's contribution to the Great War. The image of the Englishman who was too rich, relaxed and peace loving to be a good soldier (but not necessarily a coward) was nurtured by the spread of pacifism in Britain during the interwar period, so different as it was from the increasing militarisation of society enacted by the Fascist regime. This was compounded by the perceived - and partially real - decline of the efficiency of the British Army after the Great Depression and by the weakness of British foreign policy in the face of Italian, German and Japanese aggression. The latter in particular was likely to impress men like Mussolini and Ciano, probably influencing their policies in the r93os. Indeed, Mussolini's certainty that the British were reluctant to fight, and that in general they were a people not made for war, rarely wavered. The diary of Mussolini's lover, Claretta Petacci, offers many examples of this attitude on the 
part of the Duce, who repeatedly told her that the English were neither soldiers nor warriors. ${ }^{54}$ While not considering them cowards, the British nonetheless 'did not think of war because they did not need it." ${ }^{55}$ He concluded, then, that they would not fight for Danzig in $1939 .{ }^{56}$ After the Polish defeat, he believed that they would not keep fighting, because they were old and lacked a warrior mind-set. ${ }^{57}$ It is not surprising, then, that the Duce was convinced that '[his] intervention in the war will bring about [the British] defeat,' or that the day after he told Ciano that 'Britain will be beaten. Inexorably beaten. This is a reality that you [Ciano] [had] better put into your head. ${ }^{58}$ Nor is it surprising that he believed Britain, which was no longer feared by anybody, incapable of scaring the Arabs, derided by the Indians, was 'in the grip of destiny. ${ }^{59}$ As late as the beginning of 1940, Mussolini thought he could attack Yugoslavia and Greece without any reaction from France and Britain, and deluded himself that compensation offers for Italian neutrality meant that the westerners were unwilling to fight. ${ }^{60}$ Even during the war, while talking about the British conquest of Africa Orientale Italiana, Mussolini described the British as a mercantile people, eager to avoid 'sacrifices and losses. ${ }^{\text {61 }}$

The Italian press did what it could to emphasise the narrative described above. Notions that the Regia Marina and Regia Aeronautica were so strong that Britain was now the minor force in the Mediterranean, as well as stereotypes about the undisciplined, unmotivated British soldier, became commonplace. ${ }^{62}$ As early as 1934, La Stampa had observed that any foreign surveyor of 'British things' could not help but notice that British military might was going through an unprecedented period of weakening. ${ }^{63}$ In 1936, the writer and journalist Guido Piovene had written in Il Corriere that, in Britain, everyone was a pacifist, especially the common people who 'aim to remain at home with their radios, [fishing] lines and golf clubs. ${ }^{64}$ In March 1937, an article in Gerarchia reported that Britain was experiencing 'its worst military crisis in 150 years,' the causes of which were not only material but also social and moral, including the decline of the old 'mercenary' model and the scarce amount of volunteers. The consequence was an unavoidable decline in British influence worldwide, for the time being. ${ }^{65}$ Mussolini agreed, as he stated in 1937, that the British Army was unlikely to become a 'serious' one as long as it was led by Leslie Hore-Belisha, secretary of state for war. ${ }^{66}$ In March 1939, another Gerarchia contributor described how the sword (representing violence, the only virtue of the British Empire) had been replaced by gold. Not a single man in the current Empire was ready to sacrifice himself for it. The real power, he thought, was the Bank of England. ${ }^{67}$ The writer Giovanni Prezzolini was also convinced of this, telling 
his friend Pietro Calamandrei that the British and the French were too afraid to fight. His belief was justified by the notion (received with scepticism by Calamandrei) that Germany, Italy and the Soviet Union were ready to fight a proletarian war against capitalism, whereas the western allies were the capitalists to be fought against. ${ }^{68}$ Immediately after the start of the war, during the period of strained Italian relations with Germany, the press was ordered 'to make it clear that we take no part.' For a short while, the attitude towards Britain was almost balanced. ${ }^{69}$ This new 'moderate' phase ended even before Italy joined the war. Part of the reason was that the Fascist government was irked by what De Felice has described as 'the petty English vexations on the Italian naval traffic,' but the main reason appears to be the Fascists' notion that, from April, the balance was moving in favour of the Germans. ${ }^{70}$

The early months after Italy joined the war were, as we have seen, a time of triumphal tones in Italian propaganda, the press indulging in optimistic comments about the hopeless position of the British Empire. ${ }^{71}$ British military incompetence was now extended by Fascist authors to past conflicts as well. In July, Marco Ramperti mocked the British contribution to the Great War, and Luigi Barzini wrote that, while numerically superior, the British forces in the Low Countries and France had been unable to make any meaningful advance between 191 4 and 1918. ${ }^{72}$ British military setbacks in Norway and the Low Countries, as well as their idleness while Germany crushed Poland, seemed to confirm the prejudices that had been developing in the previous decade about the fundamentally weak and cowardly nature of the British people. The French defeat was explained in Gerarchia as a consequence of this British attitude. General Orlando Freri stated that 'the English contribution to the Allied cause had been truly insufficient.' Caring only about their own interests, the British refused to send France a meaningful number of soldiers, but in Kenya and Egypt, where they felt stung in their honour and interests, they showed greater aggressiveness, characteristically attributed, however, to colonial and Dominion troops. ${ }^{73}$ Perhaps the most revealing evidence about the Fascist attitude during this period is Giovanni Selvi's 'Anti-Heroic war,' or the 'English war,' which appeared in Gerarchia in June 1940 during the German offensive in France. He started by stating that this definition did not apply to the soldiers:

I do not talk of the war of those who fight. We give full honour to the soldiers and captains who knew and know how to fight and die. We say that the English war is anti-heroic, because so it is in its own traditional political system of waging war. ${ }^{74}$ 
According to Selvi, the following were elements characterising the 'anti-heroic war': coalition war; the war of the 'Cavalry Saint George,' that is, the war of bribery and mercenaries; blockade, or siege and starving war; the war of 'spider and woodworm,' as he called intelligence and propaganda war. Such tropes would appear in one form or another in most Fascist discourse, some until the very last days of the war.

Coalition war, Selvi wrote, was a long-established British tradition. Using the bogeyman of continental hegemonies, Britain had 'exhausted and dominated the European continent, [become] ruler of the seas and stripped the enemies against which it had organised the coalitions, France and Spain, rich of colonies, not sparing friends like the Netherlands.' For centuries, English influence was behind

the wars in Europe [...] with the only goal of increasing the imperial power and to crush any new force threateningly rising at the historical horizon [...]. Anybody who would dare to threaten such [British] rule would be declared an enemy of England and of God. Napoleon invading Egypt, Wilhelm thinking of the Baghdad-Bahn [railway], Mussolini asking for work for his people and conquering Ethiopia, Hitler, wanting vital space [...] they are the diabolical enemies of England. ${ }^{75}$

Echoing Mussolini's mention of the guarantees system in his declaration of war speech, Selvi claimed that the real victims of the British coalitions were those peoples who unwisely consented to take part in them, receiving a British guarantee being the greatest misfortune. ${ }^{76}$ In the current war, the coalition system had failed. Others put forward similar arguments. Pietro Caporilli wrote that British propaganda had been useful for the British, for it had convinced

other [peoples] to kill each other for centuries, in order to preserve John Bull's five feasts. It is only with [their] perfidy and disloyalty that the noble lords of the United Kingdom have perturbed the political life of nations. ${ }^{77}$

Roberto Pavese was a psychologist and professor at the University of Milan, close to the traditionalist philosopher Julius Evola. In July 1940, when Hitler's victory appeared near, he wrote an article about Britain announcing, with a triumphant and contemptuous tone, the failure of coalition war, as well as British defeat. However, Pavese declared that Britain's usual ploy to fight and win with other peoples' blood had been undermined by the Duce, who had weakened freemasonry worldwide and humiliated the League of Nations, inspiring the neutrals to resist the plutocracies' pressure to join them in their aggression. 
Germany, then, had time to act quickly against every new member of the enemy coalition. German victories, wrote Pavese, had matured from a Mussolinian seed. ${ }^{78}$ The perfidious nature of English protection was underlined by magnanimous comments on the defeated enemy, France, whose heroism and 'huge blood effort,' Orlando Freri wrote, 'had been betrayed by London. France, like Poland, Norway, Holland and Belgium, had sacrificed itself for England. ${ }^{79}$ At the same time, the British practice of hosting governments in exile running from German-occupied Europe was widely ridiculed in the press, which mocked the British 'alliance with the dead. ${ }^{30}$ The theme of the perfidious coalition war remained popular long after this initial phase. ${ }^{81}$

In what has been described as 'the optimistic summer of 1940,' the Italian press did little to hide its belief that Britain was almost finished..$^{82}$ The slow and modest Italian conquests in Somaliland, Kassala and Sidi el Barrani were inflated beyond any measure. ${ }^{83}$ At the same time, newspapers talked of panic overwhelming Britain under the shadow of German invasion. ${ }^{84}$ It was soon claimed that the Italian fleet controlled the Mediterranean, while the British fleet and air force were mocked as unwilling to test their strength against their Italian counterparts; the Regia Aeronautica's incredible claims made in July of having destroyed half the British fleet in the Mediterranean are a hint of this delusional state. ${ }^{85}$ Journalist Felice Bellotti had explained the British defeats using the old argument of the supremacy of spirit - namely, faith, love and sacrifice - over matter: 'the greatest empire of the world,' made weak by opulence, had entered its agony, enduring defeat after defeat. It was the end of the 'most colossal bluff ever seen. ${ }^{96}$ Journalist Antonio Lovato derided the comfort enjoyed by the British armoured division in North Africa, stating that the well-fed British soldiers, with 'a motor each three men,' they expected an easy walk towards Tobruk. They had, however, been disappointed by the strong Italian defence, and it was clear that it would soon be the Italian turn to advance. ${ }^{87}$

In July, Roberto Pavese had foreseen, contemptuously, the last days of Britain:

The epilogue of the British comedy is too banal, given its prologue and its development, to be called drama. It is nothing but a great example of international mob [gangsterismo was Pavese's word of choice] severely repressed and punished. [...] Today England is reduced to its island, to defend itself, to prove whether it can, at least, end well. It is the posthumous revenge of the Corse [Napoleon], expressing the feeling of the old Italic soul, decided to end once [and] for all the joke forced upon it by the barbarian [...] Mussolini will avenge Napoleon, like Hitler the Kaiser. ${ }^{88}$ 
One decade of discourse about British (and western) softness and feebleness seemed on the verge of being confirmed by facts. This was, after all, the time in which Mussolini relished the idea of Italy acquiring long-sought military glory in Egypt and of becoming a leading force in the conflict against the decadent west. ${ }^{89}$ Reading Ciano's account of Mussolini's words at this time, Britain does not appear to be a threat, rather simply a playground for Mussolini's armed forces to show Fascism's new might.

The grim winter between 1940 and 194I made clear that Britain was far from defeat and that the war was nowhere near over. Even before the beginning of the Italian military disasters, the prolonged British resistance was forcing the Fascist press to adopt a more flexible approach, accepting that Britain was not defeated yet. On 2r October 1940, Aldo Valori addressed the admiration of many Italians for British resistance, attributing it to the stubbornness of an ignorant people, the fear of the ruling class and the profits of big business for peace and defeat, but most of all to the abiding strength of Britain:

Britain is not won; [...] its resources of all kinds, accumulated during centuries of pillaging, are of course not exhausted [...] but let us not attribute to our foe moral virtues that are completely imaginary; let us not credit him with a superiority of character that he has not. ${ }^{90}$

Then defeat struck. The Regia Marina suffered a serious blow when British planes attacked it at Taranto, and the small but mobile mechanised force commanded by General O'Connor managed to rout Graziani's huge Tenth Army, quickly conquering Cyrenaica, while the Africa Orientale Italiana was soon overrun despite stubborn resistance in Eritrea. During the winter of 1940-1941, Great Britain had broken Italy's independent war effort. ${ }^{91}$

The difficult task of reconciling Italian defeats with the quite-unflattering depiction previously given of the British forced a change in the discourse: victory was still considered certain, but the war was now described as a long business. Britain was still strong, not a dead man walking and, as La Stampa commented, all the forces of the nation were to be focused on removing this last obstacle on the path to European peace. ${ }^{92}$ At the same time, the magnitude of British success was downplayed. In February, Orlando Freri wrote in Gerarchia that England, unable to attack a Germany protected by the sea, had 'concentrated all the forces available in its immense empire against Italy. The Mediterranean and Africa had assumed a central role in the economy of the war. ${ }^{93}$ However, the British advance was far from quick or decisive. Wavell's offensive had been slow despite 
his remarkable forces, which had accumulated up to 400,000 men since before the war in many mechanised and armoured units and yet were contained by the stubborn resistance of 'Italian units [lacking] means of attack and defence.' Britain had used all its strength against what it considered the 'minor mass' of the Axis, which explained Italian difficulties. ${ }^{94}$

In the context of this perceived British attempt to focus all available resources against Italy, it is important to mention how Fascist discourse considered the war in Greece as merely a theatre of the wider conflict against Britain. Therefore, Freri could write in April that the forces of Italy had faced the British Empire not just in Cyrenaica and in East Africa, but in Greece as well. ${ }^{95}$ The King of Greece was a 'monarch with no character, maintained by Britain and a slave to English imperialism. ${ }^{.96}$ Particularly revealing is that while the term 'mercenaries' was often used to describe British allies or even the forces of the Dominions, it recurs frequently when talking of Greek soldiers opposing Italy. ${ }^{97}$

During the subsequent, fluctuating phase of the war in North Africa and the Mediterranean, war propaganda adopted a somewhat more moderate approach. The British defeat in Greece was to be described as a 'new Dunkirk and a new Gallipoli. ${ }^{98}$ While the first Italian-German recapture of Cyrenaica was celebrated as far more impressive than the previous British offensive, the recent defeats had instilled caution..$^{99}$ By September 1940, some informants were suggesting the need to avoid excessively underrating British military strength, lest possible military failures have a more harmful effect on a public opinion that was too sure of itself. ${ }^{100}$ Observers condemned the lack of accuracy in the press' reports, underlining that, by the end of September, it was leading more and more Italians to distrust it. ${ }^{101}$ The defeats proved these warnings correct, and by 194I the rule was to avoid any excessive optimism and predictions of the developments of the war. ${ }^{102}$ Violent attacks on Churchill, however, were extremely common. ${ }^{103}$ The temptation of interpreting victory as a sign of weakness, or the unworthiness of the enemy, seemed too strong to be avoided by the press, which was eventually ordered on 22 April 194I to 'stop underrating the enemy and diffusing a sense of euphoria. ${ }^{104}$ One interesting example from spring $194 \mathrm{I}$ is an analysis by ministry of popular culture functionaries of a book written by Curzio Villa, the anti-British author reemerging after a long absence. The report considered the book a serious one, 'with [a] rich selection of informative facts.' However, the underrating of British weaknesses was too much:

The balance of the author wavers a little when insisting on the, certainly meaningful but not decisive, episode of the mutiny of the Invergordon 
[in 1931] to prove the great decadence of the British fleet [...] The following facts do not sustain such a theory. Also excessive is the pessimistic evaluation of the centrifugal forces of the Dominions and of the Indian revolt as very quick disintegrating germs $[s i c]$ of the Empire. The experience of the current war in which the Dominions support Great Britain, and India lies more or less quietly under the British heel, have partially debunked this postulate; postulate to be considered historically right if considered in a slow and normal process of time. ${ }^{105}$

A period of violent but indecisive battles in the desert followed, until the Italians and the Germans were forced to retreat once again from Cyrenaica. Again, the British occupation of the region was quite short. Between January and July 1942, the Axis forces in North Africa managed to overwhelm the British divisions in Cyrenaica and eventually push deep into Egypt. This led to a resurfacing of press contempt regarding both British military prowess and the supposedly weak morale of the British people; these sentiments were more in evidence than they had been since summer $1940{ }^{106}$ The Fascist authorities, however, had realised by this point that these exaggerations were counterproductive. The morbid, contented descriptions of the suffering of British civilians under German bombings almost disappeared in the early months of 1942, and by January Pavolini had recommended that the press not excessively emphasise the difficulties facing the British home front. ${ }^{107}$ In June 1942, while the Axis forces were marching through Egypt, the orders to the press set the official tone as one of 'great sobriety,' adding that 'we expect victory exclusively through [our] arms, and not from a collapse of the enemy domestic front. ${ }^{108}$ In July, the orders to the press stated that

in North Africa, the enemy fought and fights with bravery and stubbornness. To downplay such a truth with vulgar and irresponsible banalities (enemy routs, etc.) would undervalue the heroism and tenacity of our [soldiers]. Also [it is necessary to] refrain from an excessive underrating of the English generals, ${ }^{109}$ with ironic biographies, etc. The reason of [our] victories must be exclusively credited to [our] military heroism, strategic geniality, in the power of the Italian and German troops' armament. The current order is also valid for the humoristic press and extends to the maritime field (English ships [that] do not know but how to sink, etc.). ${ }^{110}$

However, articles questioning the enemy's will to fight continued to appear. Particularly interesting is an article published in September 1942 in Il Corriere, 
which provides an anthropological explanation of British warfare. If the British had 'cowardly' fled the battlefield on many occasions, it was because they waged war like their corsair ancestors who, in the infinite space of the seas, were used to attacking when superior in forces and withdrawing when the enemy was stronger. In British warfare there was no room for tactical genius in order to obviate with manoeuvre to material inferiority. This kind of warfare reduced the battle to a question of brute strength, so distant from the spiritual values that underlay Italian successes. Another reason for such a British 'strategic aberration' was that they had no problem retreating again and again because they never fought in their homeland. However, the German, Italian and Japanese forces, attacking Britain everywhere, had ruined the old British game of 'space and time.' ${ }^{111}$ Armando Tosti in La Difesa della Razza (see chapter 5) provided one peculiar, and extreme, racial explanation of the British attitude towards war. ${ }^{12}$

\section{Hatred of the Barbarians: Occupation and Bombings}

With the collapse of Graziani's Tenth Army at Beda Fomm, the British completed their first occupation of Cyrenaica, which was described by the Fascists as exceptionally harsh. In July 194I, the powerful Gerarca Alessandro Pavolini wrote that the ' 97 days of infamy' of the first British occupation of the region had given all Italians good reason to hate the authors of such barbarity. ${ }^{113}$ Another article denounced 'the ignoble and inhuman behaviour of the occupation troops,' contrasting it with Roman civilisation, ${ }^{114}$ a theme that was reprised by a successive comparison of the British and Australians with the Vandal invaders of Roman Africa. ${ }^{15}$ One letter published in Gerarchia described the 'martyrdom' inflicted on the Italian civilians by the Australians, who instead ostentatiously respected the Jewish, Arab, Greek and Indian populations:

This is the British civilization and nobleness, this is [.. .] the truth that every citizen of Benghazi lived through during the temporary rule of the alcoholic Englishmen; their army was in such a state to disgust the most savage race in the world. ${ }^{116}$

The indignation over the British occupation of Cyrenaica was popularised by the successful 1942 film Bengasi. Early in the movie, civilians are sheltering from British bombs falling on the capital of Cyrenaica. One middle-aged man (clearly characterised as a disfattista) suggests that living under British occupation might not be so bad, as 'the English are a civilised people.' He is immediately corrected by the other civilian, pointing out that the enemy purposefully 
targeted houses and hospitals. Later, the Australians troops (it is hinted that they fight instead of the English) prove to be arrogant and cruel masters, mistreating Italians, Arabs and even animals, perpetuating classic anti-British stereotypes such as the haughty officer and the brutal soldier, more often drunk than not. In the movie, as Marla Stone underlined, 'in contrast to the solid values of family, loyalty and home represented by the Italians of Bengasi, the enemy is weak and covers its weakness with arrogance and decadence. The British and their imperial troops flout international law, loot, vandalise and terrorise. The British soldiers are effeminate and old; the British officers have high-pitched voices and weak facial features. The film shows them fortifying themselves with liquor.... ${ }^{117}$

The British were also supposedly cruel to prisoners of war. Aldo Valori said that 'there are many things that make us greatly doubt that the English have an adequate concept of the principles of humanity and decency that must rule war [...], for example, the lack of care they have for the prisoners' correspondence. ${ }^{118}$ As the war went on, accusations of brutality against prisoners became more common and depicted a far harsher situation. Italian prisoners were now living in inhumane conditions, enduring harassment by British troops and (with the implication that such a thing was far worse), nonwhite gaolers. Movies like Un pilota ritorna (A Pilot Returns) pictured a harsher reality, with prisoners being brutally mistreated by British troops. ${ }^{119}$

The violent German bombing campaign against Britain was celebrated by the Fascist press. The word 'panic' was used to describe the condition of Londoners, and Englishmen in general, under the bombs. ${ }^{120}$ In September 1940 La Stampa laughed at 'English contortionism under the avenging bombs,' noticing how British agitation under the bombs contrasted with the stereotype of the calm Englishman. ${ }^{121}$ The same month, one article mocked the Londoner 'cavemen' who lived underground to find refuge from the bombings. ${ }^{122}$ In October, Luigi Barzini commented in apocalyptic tones on the 'rain of fire from the sky' annihilating London, recalling the doom of Sodom and Gomorrah. It was, in Barzini's words, historical revenge for all the miseries inflicted by Britain on the world; 'if [British] resistance persists' he concluded, 'nothing will remain of England but the skeleton. ${ }^{\prime 23}$ Mussolini was proud to announce to the Italians that he had asked for and obtained Hitler's approval to participate in the air battle against Britain (something that would later be exploited by British propaganda). ${ }^{124}$ Yet Britain kept fighting, and soon Italy was also subject to a bombing campaign. The ferocious Allied bombings on Italian (and German) cities was one of the main themes of both propaganda and more sophisticated Fascist discourse regarding wartime Britain. Yet how could one reconcile the need to denounce the 
brutality of the British campaign while praising the German one, which brought to Britain the destruction described by countless articles, for the whole length of the war? ${ }^{125}$

Civilian correspondence often underlined anti-British themes as well. One letter, dated October 194I, sent from Italian immigrants in Argentina stated that 'it is necessary that these Anglo-Saxons are exterminated for good, for with them we would live in a state of eternal slavery, given the nefarious egoism [that] is in them innate. ${ }^{126}$

Luigi Petrella underlined that the line held by Fascist propaganda in the first year of the conflict was to 'deny that the war was a destructive break with the deeply rooted rhythms and habits of Italy, while at the same time it was describing in the crudest terms the terrible consequences of German air raids over English cities. ${ }^{127}$ In this context, the point usually held was that the enemy was willingly targeting people because their goals were not military but terroristic in nature, and that Britain had started the murderous practice of bombing civilians. ${ }^{128}$ As early as 13 June 1940 , the British bombed Turin, leading radio propagandist Aldo Valori to denounce their 'murderous amateurism. ${ }^{129}$ As expressed in an order to the press on 2r November 1942, 'the enemy increasingly shows that it does not pursue a military goal, but only a criminal one [camorristico]. In any case, the Italians are not and will not allow themselves to be terrorised.' ${ }^{130}$ The employment of bombs disguised as toys or pencils was unsurprisingly the source of plenty of moral indignation. In July 194I La Stampa stated that, by using this kind of arms, the British had proven themselves once again not to belong to the world of civilised peoples. ${ }^{131}$ The themes of brutality and reluctance to risk their mens' lives appear side-by-side in an article written in June 1943 in Gerarchia, which suggested that 'the Anglo-Saxons' had still not attempted a landing in Europe, preferring instead to bomb women and children because of the awareness of the heavy price in blood that such a move would require. The Anglo-Saxons were

in a hurry to eliminate Italy from the conflict, and they would like to do it without a fight. Never were our enemies so worried to spare the blood of our fighters, shedding the one of our children, of our women, of our elders, of our nurses, and destroying our churches, our millenary monuments. ${ }^{132}$

Their goal was, then, to break the spirit of the Italian people, the tools used including the usual 'threats and wheedling, the explosive pencil together with the flattering leaflet, the brutal bombing with the sentimental appeal, the humiliating command with the praise of our soldiers. ${ }^{3}{ }^{133}$ Brogi wondered how much more 
worried they would have been if, being aware of the real spiritual endurance of the Italian people, they would realise that 'there are not few people waiting for the Anglo-Americans, ${ }^{134}$ in Sicily, Sardinia, Calabria or Grosseto, to avenge their killed or maimed children, [their] women bombed on peaceful roads, old men buried under the ruins. ${ }^{\prime} 35$ The same month, Concetto Pettinato underlined how, throughout their history, the British had proven themselves to have 'a heart of stone. ${ }^{136}$ However, this kind of discourse, which showed the Italians as victims of British cruelty, was not always appreciated by Fascist censorship. The orders to the press were to avoid any sentimentality concerning the loss of human lives and the visits of personalities to the population (the term used was pietismo), to adopt a 'virile polemic tone' and focus on the barbarity and cowardice of the enemy. ${ }^{137}$ The Fascist authorities felt that too little space had been given to describing Anglo-Saxon cruelty by the press. In May 1943, the orders to the press lamented that 'the polemic against the Anglo-American pilots, murderers of children and women, is not "cutting" enough. [It is necessary to] develop the concept of barbarism, gangsterismo, cowardice. Avoid any sentimental tone. Do not mention, for now, reprisals. ${ }^{138}$ The appeal did not have a long-lasting effect and, later the same month, the orders to the press mentioned how 'after some days, the polemic against the enemy has, again, lost its "cutting": the English and the Americans keep fighting the war as brigands. The reaction of the Italian press is weak. ${ }^{139}$ The order added that one newspaper had claimed 'Italians are angels' - such rhetoric was to be avoided, since it was reminiscent of the 'old despicable commonplaces of the "good Italian".'140 The Fascist regime had sought to turn the Italian people into a hard race of conquerors: the only acceptable response to the bombings was hatred, not images of passive martyrs. The order to the press on 17 May 1943 gives a picture of what this meant:

Today we witness cowardly, atrocious and inhuman acts [...] that have no precedent and recall the far times of the barbarian invasions. The reaction of the Italian press against those atrocities must be dealt with a strong sentiment, and most of all must be strongly felt by the writers, without pietisms. GENERAL DIRECTIVE: hatred against the barbarians. ${ }^{141}$

By 1944, the discourse focused on the subject of the brutality and arrogance of the invaders, the 'new barbarians,' worse than the old, because unlike them they showed no respect for the artistic treasures of Italy. ${ }^{142}$

The stereotype about the Briton who could not or would not not fight had largely disappeared. Concetto Pettinato, a journalist well known for his hatred of the Western democracies, wrote in January 1943 that 
if the British islands had been inhabited by 50 millions of Italians instead of 50 millions of Englishmen, after Dunkirk Churchill would have been forced to wear a fake beard and run from his home from the window [and] King George would have escaped by night [...] But the British islands are inhabited by Englishmen, instead, and forty-three months since Dunkirk the war still lasts, King George is still on his throne, Churchill smokes his cigars and Eden did not stop talking about fancy ties. ${ }^{143}$

Pettinato's new point of view somehow mirrored Mussolini's in 1917, when he had implied that, unlike the Italians, the British were capable of remaining unified behind their national cause. Once again, the Fascist discourse had gone full circle. 